\title{
Georgenia muralis gen. nov., sp. nov., a novel actinobacterium isolated from a medieval wall painting
}

1 Institut für Bakteriologie, Mykologie und Hygiene, Veterinärmedizinische Universität, A-1210 Wien, Austria

2 Institut für Mikrobiologie und Genetik, Universität Wien, A-1030 Wien, Austria

3 Institut für Angewandte Mikrobiologie, Justus Liebig-Universität Giessen, D-35392 Giessen, Germany

${ }^{4}$ DSMZ - Deutsche Sammlung von Mikroorganismen und Zellkulturen $\mathrm{GmbH}$, D38124 Braunschweig, Germany

\author{
Petra Altenburger, ${ }^{1,2}$ Peter Kämpfer, ${ }^{3}$ Peter Schumann, ${ }^{4}$ \\ Dietmar Vybiral, ${ }^{2}$ Werner Lubitz ${ }^{2}$ and Hans-Jürgen Busse ${ }^{1,2}$
}

Author for correspondence: Hans-Jürgen Busse. Tel: +43125077 2128. Fax: +431250772190.
e-mail: hans-juergen.busse@vu-wien.ac.at

Two bacterial strains, designated $1 \mathrm{~A}-\mathrm{C}^{\top}$ and $3 \mathrm{~A}-1$, were studied and, using these results and previously published data, taxonomically classified. Cells of the strains exhibited a rod-coccus cycle. The peptidoglycan determined for $1 \mathrm{~A}-\mathrm{C}^{\mathrm{T}}$ was of type A4 $\alpha$ with lysine as the diagnostic cell-wall diamino acid and an interpeptide bridge of L-Lys $\leftarrow$ L-Glu. The menaquinone systems of the two strains contained $\mathrm{MK}-8\left(\mathrm{H}_{4}\right)(82-94 \%)$ and $\mathrm{MK}-7\left(\mathrm{H}_{4}\right)(3-11 \%)$. The polar lipid profiles consisted of diphosphatidylglycerol, phosphatidylglycerol, phosphatidylinositol mannoside, two unidentified phospholipids and an unidentified glycolipid. The fatty acid profiles contained predominantly ai- $C_{15: 0}$ and significant amounts of i-C14:0 and i-C15:1 fatty acids. Genomic fingerprints clearly distinguished strains $1 \mathrm{~A}-\mathrm{C}^{\top}$ and $3 \mathrm{~A}-1$ from each other. DNA-DNA relatedness between the two strains (92\%) demonstrated that they are members of a single species. Analyses of the $16 \mathrm{~S}$ rDNA sequences of strains $1 \mathrm{~A}-\mathrm{C}^{\top}$ and $3 \mathrm{~A}-1$, which were almost identical ( $99.6 \%$ sequence similarity), and comparison with corresponding sequences demonstrated that they represent a novel lineage within the suborder Micrococcineae, most closely related to species of the genera Beutenbergia, Bogoriella and Cellulomonas (94.7-95.7\% sequence similarity). The results demonstrate that the two strains are members of a single new genus and a single novel species. Thus, the name Georgenia muralis gen. nov., sp. nov. is proposed. The type strain is strain 1A-C $(=$ DSM 14418 $=$ CCM 4963 $)$. Another strain of the species is strain 3A-1 (= DSM $14419=$ CCM 4964).

Keywords: Georgenia muralis gen. nov., sp. nov., 16S rDNA sequence, chemotaxonomy, phenotypic characteristics

\section{INTRODUCTION}

In a recent study, several bacterial strains isolated from a damaged medieval wall painting from a church in St Georgen, Styria (Austria), were characterized by means of physiological, biochemical and chemotaxonomic traits as well as analyses of partial 16S rDNA sequences (Altenburger et al., 1996). These isolates were identified as members of the classes Actinobacteria and Proteobacteria and the aerobic, endospore-

Abbreviations: $B O X-P C R, B O X$ A element-derived PCR; ERIC-PCR, enterobacterial repetitive intergenic consensus PCR; REP-PCR, repetitive extragenic palindromic PCR.

The EMBL accession numbers for the $16 \mathrm{~S}$ rDNA sequences of strains $1 A-C^{\top}$ and $3 A-1$ are respectively $X 94155$ and AJ308598. forming bacteria (Altenburger et al., 1996; Wieser et al., 1999; H.-J. Busse, unpublished results). A pair of strains (originally designated G5 and G6) included in the former study could not be affiliated to any established genus. Due to the uniqueness of their chemotaxonomic characteristics and the distance from any established taxon indicated from partial $16 \mathrm{~S}$ rDNA sequences, the two strains were re-examined in order to determine their taxonomic status.

In this paper, strains $1 \mathrm{~A}-\mathrm{C}^{\mathrm{T}}\left(=\mathrm{G} 5^{\mathrm{T}}\right)$ and $3 \mathrm{~A}-1(=\mathrm{G} 6)$ were characterized and classified. On the basis of our results, it is suggested that strains $1 \mathrm{~A}-\mathrm{C}^{\mathrm{T}}$ and $3 \mathrm{~A}-1$ should be placed in a new genus as a novel species, for which the name Georgenia muralis gen. nov., sp. nov. is proposed. 


\section{METHODS}

Bacterial strains and culture conditions. Strains $1 \mathrm{~A}-\mathrm{C}^{\mathrm{T}}$ and 3A-1 were isolated from a medieval wall painting in the church of St Georgen, Styria, Austria, as described previously (Altenburger et al., 1996). Isolate 3A-0 was detected as a colony variant of strain 3A-1. For morphological, physiological and chemotaxonomic studies, strains were cultivated in liquid casein mineral medium (CasMM) and on CasMM agar plates unless indicated otherwise (Altenburger et al., 1996).

Morphological, physiological and biochemical characterization. Cell morphology was examined over 14 days by phasecontrast microscopy (Leitz DMRB). Gram behaviour was investigated by Gram staining, $\mathrm{KOH}$ test and aminopeptidase test (Moaledj, 1986). Growth on PYES agar $(0 \cdot 3 \%$ casein from peptone, $0.3 \%$ yeast extract, $0 \cdot 23 \%$ disodium succinate, $1.5 \%$ agar, $\mathrm{pH} 7 \cdot 2$ ) and $\mathrm{R} 2 \mathrm{~A}$ agar (Oxoid) was tested at room temperature. Anaerobic growth was studied in an atmosphere of $95 \% \mathrm{~N}_{2}$ and $5 \% \mathrm{CO}_{2}$ in an aerostat WA 2600 (Heraeus Instruments) at 28 and $37^{\circ} \mathrm{C}$ on CasMM agar. Growth at different temperatures $(4,28,37,44$ and $48{ }^{\circ} \mathrm{C}$ ) was tested on CasMM agar. Tolerance of $\mathrm{NaCl}$ was tested on CasMM agar at $\mathrm{NaCl}$ concentrations of $1,3,5,7$, 10 and $15 \%(\mathrm{w} / \mathrm{v}) \cdot \mathrm{pH}$ tolerance was examined on CasMM buffered as described by Nielsen et al. (1995). Carbon source utilization tests, sugar fermentation and qualitative enzyme tests were carried out in microtitre plates according to Kämpfer et al. (1991).

Decomposition of cellulose was tested on CasMM with the modification that casein was replaced by either $0.5 \% \alpha$ cellulose (Sigma) or $0 \cdot 2 \%$ cellulose azur (Sigma).

Hydrolysis of starch, Tween 80 and casein was determined on CasMM agar supplemented with $1 \%$ potato starch, $0.5 \%$ Tween 80 or $5 \%$ casein. Tests for oxidase, catalase, nitrate reduction, $\mathrm{H}_{2} \mathrm{~S}$ production, indole production and urease activity were performed as described by Smibert \& Krieg (1994).

Chemotaxonomic characterization. Isoprenoid quinones were extracted by the method of Tindall (1990) and analysed by HPLC as described by Altenburger et al. (1996). Extraction and analysis of polar lipids by two-dimensional TLC were performed according to Ventosa et al. (1993). Fatty acids were prepared as described previously (Osterhout et al., 1991). Fatty acid methyl esters were analysed by GC using a Hewlett Packard HP 6890 Series GC system with an HP-5 capillary $(30 \mathrm{~m} \times 0.32 \mathrm{~mm}$; film thickness, $0 \cdot 25 \mu \mathrm{m})$. Cell-wall preparation and analysis of the peptidoglycan type were done according to Groth et al. (1997a). Extraction and detection of polyamines were done as described by Busse \& Auling (1988) and Altenburger et al. (1997). Whole-cell protein patterns were examined as described by Altenburger et al. (1996).

DNA base composition and DNA-DNA hybridization. DNA isolation and analysis of the $\mathrm{G}+\mathrm{C}$ content were done according to Auling et al. (1986) and Kaneko et al. (1986). DNA-DNA hybridization was performed as described previously (Huß et al., 1983; Jahnke, 1992).

16S rDNA sequence analysis. Extraction of DNA, amplification of the 16S rRNA genes and sequence analyses were done as described by Wieser et al. (1999). DNA sequences were aligned with the sequences currently available from the EMBL database using the program FASTA (Pearson \& Lipman, 1988). A total of 1321 unambiguously determined nucleotides between positions 41 and 1362 (Escherichia coli numbering; Brosius et al., 1978) was used for comparative analyses. Pairwise evolutionary distances were calculated by the method of Jukes \& Cantor (1969). A phylogenetic dendrogram was constructed by the neighbour-joining method (Saitou \& Nei, 1987) with the program NEIGHBOR. The stability of the groupings was estimated by bootstrap analysis (1000 replications) using the programs of the PHYLIP package (Felsenstein, 1993). All software was taken from the Wisconsin Package (GCG, 1995).

rep-PCR. ERIC-PCR (enterobacterial repetitive intergenic consensus PCR), REP-PCR (repetitive extragenic palindromic PCR) and BOX-PCR (BOX A element-derived PCR) were carried out according to Louws et al. (1994) with the modifications described by Wieser \& Busse (2000). REPPCR was modified in that the primer annealing temperature was lowered to $40^{\circ} \mathrm{C}$.

\section{RESULTS AND DISCUSSION}

\section{Morphological, biochemical and physiological characteristics}

Observation of cell morphology revealed that cells of strains $1 \mathrm{~A}-\mathrm{C}^{\mathrm{T}}$ and $3 \mathrm{~A}-1$ exhibited a rod-coccus cycle. Cells of exponentially growing cultures were short, coccoid rods with a width of about $1 \mu \mathrm{m}$ and a length of about $2 \mu \mathrm{m}$. Stationary-phase cells appeared as cocci (approx. $1 \mu \mathrm{m}$ in diameter), occurring singly or in small clusters. Endospores and motile cells were not observed. Colonies observed after 6 days growth on CasMM agar were circular, convex, yellow and transparent. Maximum colony size (2 $\mathrm{mm}$ in diameter) was reached after 2 weeks incubation at room temperature on CasMM agar. Cells of the two strains stained Gram-positive. They were aminopeptidase-negative and displayed Gram-positive behaviour in the $\mathrm{KOH}$ test. Both strains were weakly catalase- and oxidasepositive. Good growth was observed on media with a low nutrient content such as CasMM agar, R2A agar and PYES agar. Aerobically, cells grew well at room temperature and at 28 and $37^{\circ} \mathrm{C}$. Weak growth was observed at $4{ }^{\circ} \mathrm{C}$ and no growth was observed at 44 or $48^{\circ} \mathrm{C}$. Both strains grew well under anaerobic conditions at 28 and $37^{\circ} \mathrm{C}$. The two strains grew well between 0 and $5 \%(\mathrm{w} / \mathrm{v}) \mathrm{NaCl}$ and moderately at $7 \%$ (w/v) NaCl. No growth was observed at concentrations of 10 or $15 \%(\mathrm{w} / \mathrm{v}) \mathrm{NaCl}$. The $\mathrm{pH}$ range for growth was pH 6-9. Biochemically, strains $1 \mathrm{~A}-\mathrm{C}^{\mathrm{T}}$ and 3A-1 could only be distinguished from each other by the assimilation of D-mannose, only observed in 1A$\mathrm{C}^{\mathrm{T}}$. No characters were found to distinguish colony variant 3A-0 from strain 3A-1. Detailed physiological and biochemical properties are given in the species description below.

\section{S rDNA sequence analyses}

The almost complete 16S rDNA sequences of strains $1 \mathrm{~A}-\mathrm{C}^{\mathrm{T}}$ and $3 \mathrm{~A}-1$ (1417 and $1429 \mathrm{nt}$, respectively) shared $99.6 \%$ similarity. Comparison with corresponding sequences of members of the class Actinobacteria demonstrated that strains $1 \mathrm{~A}-\mathrm{C}^{\mathrm{T}}$ and $3 \mathrm{~A}-1$ 


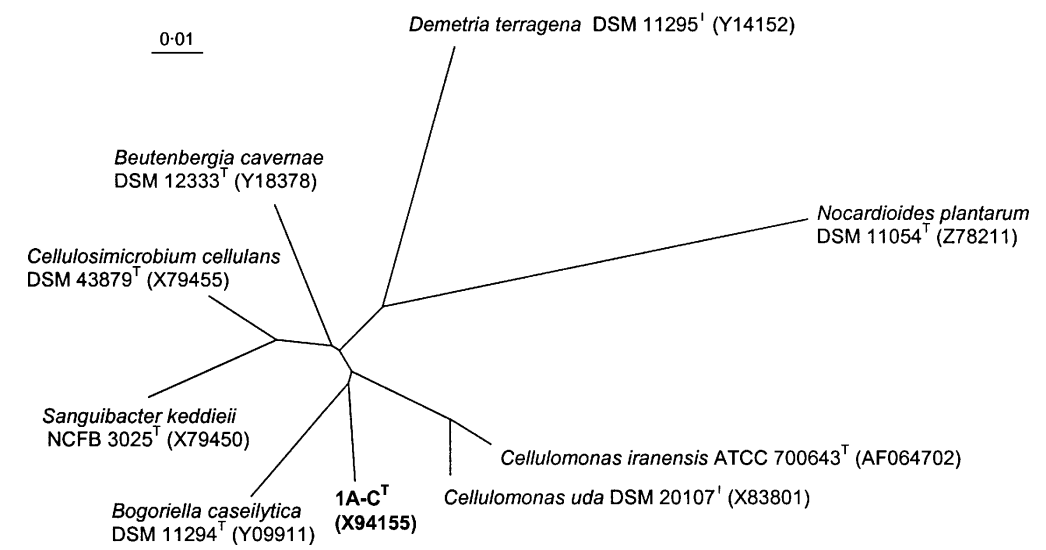

Fig. 1. Phylogenetic tree based on $16 \mathrm{~S}$ rRNA sequence comparisons indicating the phylogenetic position of strain $1 \mathrm{~A}-\mathrm{C}^{\mathrm{T}}$ within the suborder Micrococcineae. Nocardioides plantarum DSM $11054^{\top}$ was included as an outgroup. Bar, 1 substitution per 100 nt.

Table 1. Patterns of $16 \mathrm{~S}$ rRNA signature nucleotides that define strains $1 A-C^{\top}$ and $3 A-1$, Beutenbergia cavernae DSM $12333^{\top}$ and the families Bogoriellaceae and Cellulomonadaceae

Positions are numbered according to the E. coli numbering. The following signature nucleotides were identical in all four taxa analysed: $41-401(\mathrm{G}-\mathrm{C}), 45-396(\mathrm{U}-\mathrm{G}), 99(\mathrm{U}), 142-221(\mathrm{C}-\mathrm{G})$, 248-276 (C-G), 258-268 (G-C), 379-384 (C-G), 502-543 (G-C), 586-755 (C-G), 591-648 (U-A), 610 (A), 602-636 (C-G), 615-625 (A-U), 616-624 (G-C), 630 (C), 660-745 (G-C), 670-736 (A-U), 1244-1293 (C-G), 1254-1283 (G-C) and 1310-1327 (G-C).

\begin{tabular}{|lcccc|}
\hline Position(s) & $\begin{array}{c}\text { Strains 1A-C } \\
\text { and 3A-1 }\end{array}$ & $\begin{array}{c}\text { B. cavernae } \\
\text { DSM 12333 }\end{array}$ & Bogoriellaceae $^{\text {3A }}$ & Cellulomonadaceae \\
\hline $144-178$ & $\mathrm{U}-\mathrm{G}$ & $\mathrm{C}-\mathrm{G}$ & $\mathrm{U}-\mathrm{G}$ & $\mathrm{C}-\mathrm{G}$ \\
$140-223$ & $\mathrm{G}-\mathrm{U}$ & $\mathrm{G}-\mathrm{U}$ & $\mathrm{G}-\mathrm{U}$ & $\mathrm{C}-\mathrm{G}$ \\
$293-304$ & $\mathrm{G}-\mathrm{U}$ & $\mathrm{G}-\mathrm{U}$ & $\mathrm{G}-\mathrm{U}$ & $\mathrm{G}-\mathrm{C}$ \\
$407-435$ & $\mathrm{~A}-\mathrm{U}$ & $\mathrm{A}-\mathrm{U}$ & $\mathrm{A}-\mathrm{U}$ & $\mathrm{C}-\mathrm{G}$ \\
$589-650$ & $\mathrm{U}-\mathrm{A}$ & $\mathrm{U}-\mathrm{A}$ & $\mathrm{C}-\mathrm{G}$ & $\mathrm{U}-\mathrm{A}$ \\
$612-628$ & $\mathrm{G}-\mathrm{C}$ & $\mathrm{G}-\mathrm{C}$ & $\mathrm{C}-\mathrm{G}$ & $\mathrm{C}-\mathrm{G}$ \\
$668-738$ & $\mathrm{~A}-\mathrm{U}$ & $\mathrm{A}-\mathrm{U}$ & $\mathrm{A}-\mathrm{U}$ & $\mathrm{U}-\mathrm{A}$ \\
$839-874$ & $\mathrm{C}-\mathrm{G}$ & $\mathrm{U}-\mathrm{A}$ & $\mathrm{C}-\mathrm{G}$ & $\mathrm{C}-\mathrm{G}$ \\
863 & $\mathrm{U}$ & $\mathrm{U}$ & $\mathrm{U}$ & A \\
$1133-1141$ & $\mathrm{G}-\mathrm{C}$ & $\mathrm{A}-\mathrm{U}$ & $\mathrm{A}-\mathrm{U}$ & $\mathrm{G}-\mathrm{C}$ \\
$1134-1140$ & $\mathrm{G}-\mathrm{C}$ & $\mathrm{C}-\mathrm{G}$ & $\mathrm{C}-\mathrm{G}$ & $\mathrm{G}-\mathrm{C}$ \\
$1263-1272$ & $\mathrm{G}-\mathrm{U}$ & $\mathrm{A}-\mathrm{U}$ & $\mathrm{A}-\mathrm{U}$ & $\mathrm{A}-\mathrm{U}$ \\
1414 & $\mathrm{C}$ & $\mathrm{U}$ & $\mathrm{C}$ & $\mathrm{U}$ \\
\hline
\end{tabular}

clustered within the suborder Micrococcineae. Highest 16S rDNA sequence similarity values were obtained with members of the genus Cellulomonas (95.5-95.7 $\%$ ), Beutenbergia cavernae $(95.5 \%)$ and Bogoriella caseilytica $(94.7 \%)$; the data indicate that strains $1 \mathrm{~A}-\mathrm{C}^{\mathrm{T}}$ and $3 \mathrm{~A}-1$ have a closer relationship to the genus Cellulomonas. Assessment of phylogenetic position placed $1 \mathrm{~A}-\mathrm{C}^{\mathrm{T}}$ on the Bogoriella caseilytica lineage, close to the branching point with the Cellulomonas lineage (Fig. 1) within the radiation of representative taxa of the suborder Micrococcineae (Stackebrandt et al., 1997). While the branching point between the Bogoriella caseilytica and Cellulomonas lineages received strong support from the calculated bootstrap value (935), the branching point of $1 \mathrm{~A}-\mathrm{C}^{\mathrm{T}}$ did not appear to be very stable (538).
The presence of almost all of the signature nucleotides in the 16S rDNA sequences (positions 23-1461, E. coli numbering) of isolates $1 \mathrm{~A}-\mathrm{C}^{\mathrm{T}}$ and $3 \mathrm{~A}-1$ confirmed their placement within the suborder Micrococcineae (Stackebrandt et al., 1997) (Table 1). Only the A-A pair (positions 722-733) was replaced by a $\mathrm{G}-\mathrm{G}$ pair in strains $1 \mathrm{~A}-\mathrm{C}^{\mathrm{T}}$ and $3 \mathrm{~A}-1$. However, it has to be noted that Beutenbergia cavernae DSM $12333^{\mathrm{T}}$ shares this characteristic signature nucleotide pair with strains $1 \mathrm{~A}-\mathrm{C}^{\mathrm{T}}$ and $3 \mathrm{~A}-1$. Screening for 33 family-specific signatures (Stackebrandt et al., 1997; Stackebrandt \& Schumann, 2000) revealed highest agreement with the families Bogoriellaceae $(84.8 \%)$ and Cellulomonadaceae $(72.7 \%)$. Investigation of the corresponding signatures of Beutenbergia cavernae revealed an accordance of $81.8 \%$. These values do not indicate 


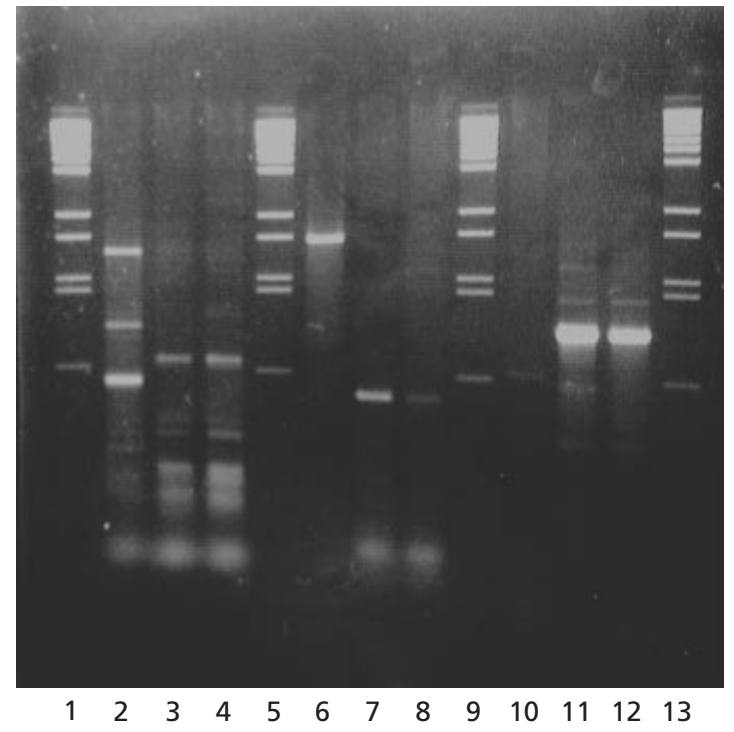

Fig. 2. Genomic fingerprints of isolates $1 A-C^{\top}$ (lanes 2,6 and 10), 3A-0 (lanes 3, 7 and 11) and 3A-1 (lanes 4, 8 and 12) generated by ERIC- (lanes 2-4), REP- (lanes 6-8) and BOX- (lanes 10-12) PCR. Lanes 1, 5, 9 and 13; lambda DNA BstEll digest.

affiliation of the two strains to any of these families. The phylogenetic distance and the low 16S rDNA sequence similarities of $1 \mathrm{~A}-\mathrm{C}^{\mathrm{T}}$ and $3 \mathrm{~A}-1$, as well as the low congruence in signature nucleotides with established taxa, indicate that the two strains are at least members of a new genus.

\section{Genomic fingerprinting}

Several studies (Van Belkum et al., 1992; Woods et al., 1992; Versalovic et al., 1993; Wieser \& Busse, 2000; Kainz et al., 2000) have demonstrated that genomic fingerprint techniques are suitable for the investigation of relationships at the species level. In order to investigate the relationship between the two strains, they were subjected to REP-PCR employing ERIC-, REP- and BOX-PCR. Strains $1 A-C^{T}$ and $3 A-1$ each displayed a distinct band pattern (Fig. 2), indicating their genotypic heterogeneity. Almost identical genomic fingerprints were obtained for strain 3A-1 and its colony variant $3 \mathrm{~A}-0$, thus demonstrating their clonal relatedness.

\section{Chemotaxonomic characteristics}

The peptidoglycan of strains $1 \mathrm{~A}-\mathrm{C}^{\mathrm{T}}$ and $3 \mathrm{~A}-1$ contained Ala, Glu and Lys in a molar ratio of $2: 2: 1$. Enantiomeric analysis of cell-wall diamino acids resulted in the detection of D-Ala, L-Ala, D-Glu, L-Glu and L-Lys. According to these data, it was concluded that strains $1 \mathrm{~A}-\mathrm{C}^{\mathrm{T}}$ and $3 \mathrm{~A}-1$ contain peptidoglycan of type A $4 \alpha$ (Schleifer \& Kandler, 1972), murein type A11.54 (DSMZ, 1998). So far, this peptidoglycan type has only been found in Arthrobacter sulfureus (Stack-

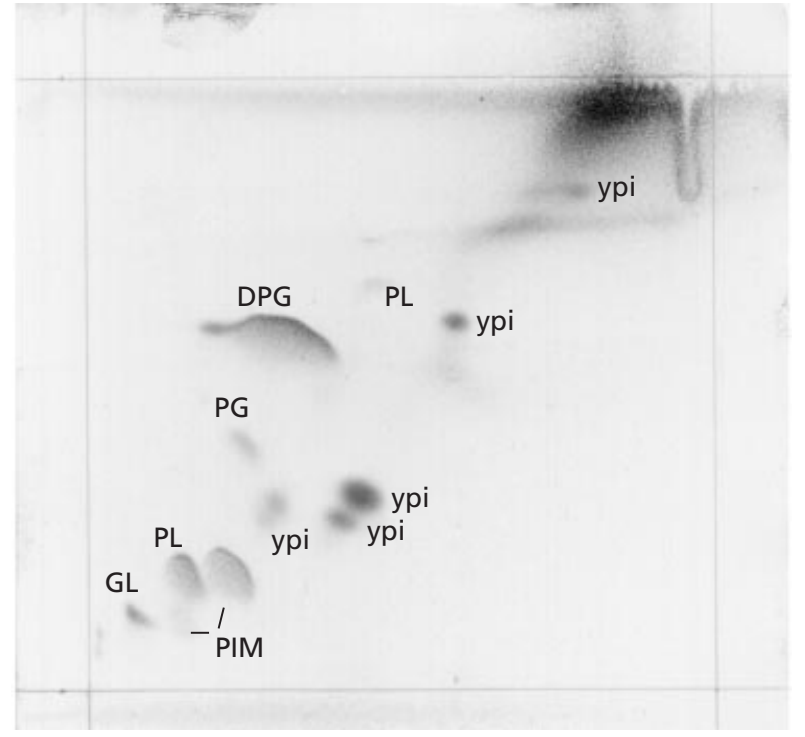

Fig. 3. Two-dimensional TLC of polar lipid extracts from strain $1 \mathrm{~A}-\mathrm{C}^{\top}$ stained with molybdatophosphoric acid. DPG, Diphosphatidylglycerol; GL, unknown glycolipid; PG, diphosphatidylglycerol; PIM, phosphatidylinositol mannoside; $\mathrm{PL}$, unknown phospholipid; ypi, yellow pigment.

ebrandt et al., 1983b) and Beutenbergia cavernae (Groth et al., 1999b). In contrast, members of the phylogenetically closely related genus Cellulomonas are described as having peptidoglycan type $\mathrm{A} 4 \beta$, with the characteristic diamino acid ornithine (Rainey et al., 1995). Analysis of the quinone systems of strains $1 \mathrm{~A}-\mathrm{C}^{\mathrm{T}}$ and $3 \mathrm{~A}-1$ revealed $\mathrm{MK}-8\left(\mathrm{H}_{4}\right)$ as the major compound $(82-94 \%)$ and, in contrast to previous studies (Altenburger et al., 1996), MK-7 $\left(\mathrm{H}_{4}\right)$ as the minor compound (3-11\%). Within the suborder $M i$ crococcineae, a quinone system with the predominant menaquinone MK-8 $\left(\mathrm{H}_{4}\right)$ has been reported for several genera including Bogoriella and Beutenbergia (Stackebrandt et al., 1983a; Groth et al., 1997a, b, 1999a, b; Martin et al., 1997; Prauser et al., 1997; Schumann et al., 1997; Maszenan et al., 2000). In contrast, Cellulomonas has been reported to have a menaquinone system with MK-9 $\left(\mathrm{H}_{4}\right)$ as the major compound (Stackebrandt \& Prauser, 1992). However, Beutenbergia cavernae is the only species that shares the combination of a predominant $\mathrm{MK}-8\left(\mathrm{H}_{4}\right)$ and the rare murein type A11.54 with strains $1 \mathrm{~A}-\mathrm{C}^{\mathrm{T}}$ and $3 \mathrm{~A}-1$.

The polar lipid patterns of the two isolates were qualitatively identical. As shown for strain $1 \mathrm{~A}-\mathrm{C}^{\mathrm{T}}$ (Fig. 3), they were characterized by the occurrence of diphosphatidylglycerol, phosphatidylglycerol and phosphatidylinositol mannoside. In addition, two unidentified phospholipids and one unidentified glycolipid were detected. Lack of phosphatidylinositol and the occurrence of phosphatidylglycerol or phosphatidylinositol mannoside clearly distinguish strains 1A$\mathrm{C}^{\mathrm{T}}$ and 3A-1 from Beutenbergia cavernae and members of the genus Cellulomonas (Groth et al., 1999b; Stackebrandt \& Prauser, 1992). 
Table 2. Cellular fatty acid composition of strains $1 A-C^{\top}$ and $3 \mathrm{~A}-1$

Values are percentages of total fatty acids.

\begin{tabular}{|lrc|}
\hline Fatty acid & 1A-C $^{\mathbf{T}}$ & 3A-1 \\
\hline i-C14:1 & $0 \cdot 6$ & $2 \cdot 3$ \\
i-C14:0 & $6 \cdot 0$ & $6 \cdot 4$ \\
C14:0 & $0 \cdot 5$ & $2 \cdot 9$ \\
i-C15:1 & $4 \cdot 1$ & $4 \cdot 2$ \\
i-C15:0 & $4 \cdot 9$ & $2 \cdot 8$ \\
ai-C15:0 & $66 \cdot 6$ & $62 \cdot 1$ \\
i-C16:1 & $2 \cdot 4$ & $2 \cdot 4$ \\
i-C16:0 & $1 \cdot 4$ & - \\
C16:0 & $0 \cdot 6$ & - \\
Unknown 1 & $2 \cdot 0$ & - \\
Unknown 2 & $8 \cdot 2$ & $17 \cdot 1$ \\
Unknown 3 & $2 \cdot 7$ & - \\
\hline
\end{tabular}

Fatty acid profiles of $1 \mathrm{~A}-\mathrm{C}^{\mathrm{T}}$ and $3 \mathrm{~A}-1$ were dominated by branched acids of the iso- and anteiso-type with the predominant acid ai-C15:0, along with significant amounts of i-C14:0 and i-C15:1 and an unknown compound (Table 2). Strains 1A-C $C^{T}$ and 3A-1 could be distinguished from Beutenbergia cavernae DSM $12333^{\mathrm{T}}$ (Groth et al., 1999b) by quantitative differences in $\mathrm{i}-\mathrm{C} 14: 0$, i-C15:0 and $\mathrm{C} 16: 0$ fatty acids. The fatty acid profiles of $1 \mathrm{~A}-\mathrm{C}^{\mathrm{T}}$ and $3 \mathrm{~A}-1$ also discriminate the two strains from members of the genus Cellulomonas (Funke et al., 1995). In addition to the major compound ai-C15:0, species of the genus Cellulomonas are reported to contain high concentrations of the unbranched fatty acid C16:0, which was detected in only small amounts in strain $1 \mathrm{~A}-\mathrm{C}^{\mathrm{T}}$.

Analysis of the polyamines of strain $1 \mathrm{~A}-\mathrm{C}$ revealed a pattern with relatively low concentrations of polyamines. Its pattern consisted of the major compounds spermidine $\left[0.26 \mu \mathrm{mol}(\mathrm{g} \text { dry } \mathrm{wt})^{-1}\right]$ and spermine $\left[0 \cdot 18 \mu \mathrm{mol}(\mathrm{g} \text { dry wt })^{-1}\right]$ and small amounts of cadaverine $\left[0.02 \mu \mathrm{mol}(\mathrm{g} \text { dry wt})^{-1}\right]$. Similar polyamine patterns have already been reported for other Actinobacteria such as members of the genera Corynebacterium and Agromyces (Altenburger et al., 1997). However, this feature clearly differentiates strains $1 \mathrm{~A}-\mathrm{C}^{\mathrm{T}}$ and 3A-1 from other Gram-positive genera that contain MK-8 $\left(\mathrm{H}_{4}\right)$ as the predominant menaquinone and which were shown to contain significantly higher concentrations of polyamines (5- to 10-fold), such as Nocardioides, Terrabacter, Terracoccus and Sanguibacter (Busse \& Schumann, 1999).

A quinone system consisting of menaquinone MK$8\left(\mathrm{H}_{4}\right)$ and the occurrence of L-Lys in the peptidoglycan have also been reported for the genera Demetria and Bogoriella, but the polar lipid patterns and the fatty acid profiles of these genera clearly differ from those of strains 1A-C ${ }^{\mathrm{T}}$ and 3A-1 (Groth et al., 1997a, b; Table 3) confirming the distant relationships of the two isolates indicated by analysis of $16 \mathrm{~S}$ rDNA sequences.

\section{DNA base composition and DNA relatedness}

The $\mathrm{G}+\mathrm{C}$ content of strain $1 \mathrm{~A}-\mathrm{C}^{\mathrm{T}}$ was $69 \cdot 7 \mathrm{~mol} \%$. The DNA-DNA relatedness between strains $1 \mathrm{~A}-\mathrm{C}^{\mathrm{T}}$ and $3 \mathrm{~A}-1$ was $92 \%$.

\section{Taxonomic considerations}

Both the levels of $16 \mathrm{~S}$ rDNA sequence similarity to members of the genera Cellulomonas, Bogoriella and Beutenbergia and differences in signature nucleotides (Table 1) prevent assignment of strains $1 \mathrm{~A}-\mathrm{C}^{\mathrm{T}}$ and $3 \mathrm{~A}-1$ to any of these three genera. Although the two strains share some chemotaxonomic characteristics with related genera, they can be distinguished from members of Cellulosimicrobium, Cellulomonas, Bogoriella and Beutenbergia on the basis of peptidoglycan type, fatty acid composition, polar lipid profile and/or quinone system (Table 3).

Table 3. Differential characteristics of Georgenia gen. nov. and related taxa

Data were taken from this study and from Groth et al. (1999b) (Beutenbergia), Groth et al. (1997a) (Bogoriella), Groth et al. (1997b) (Demetria), Schumann et al. (2001) (Cellulosimicrobium) and Stackebrandt \& Prauser (1992) and Funke et al. (1995) (Cellulomonas).

\begin{tabular}{|c|c|c|c|c|c|c|}
\hline Characteristic & Georgenia & Beutenbergia & Bogoriella & Demetria & Cellulosimicrobium & Cellulomonas \\
\hline Cell morphology & Rod-coccus cycle & Rod-coccus cycle & Irregular rods, coccoid & Coccoid, short rods & $\begin{array}{l}\text { Primary mycelium, } \\
\text { rod, coccoid }\end{array}$ & Branched rods \\
\hline Major fatty acids & $\begin{array}{c}\text { ai-C15:0, ai-C15:1, } \\
\text { i-C14:0 }\end{array}$ & i-C15:0, ai-C15:0 & ai-C15:0 & $\begin{array}{l}\mathrm{C} 18: 1, \mathrm{C} 18: 0, \mathrm{C} 17: 0, \\
\quad \text { ai-C17:0, C16:0 }\end{array}$ & $\begin{array}{c}\text { ai-C15:0, i-C16:0, } \\
\text { C16:0, i-C15:0 }\end{array}$ & ai-C15:0, C16:0 \\
\hline Major menaquinone & $\mathrm{MK}-8\left(\mathrm{H}_{4}\right)$ & MK-8 $\left(\mathrm{H}_{4}\right)$ & MK-8 $\left(\mathrm{H}_{4}\right)$ & MK $-8\left(\mathrm{H}_{4}\right)$ & MK-9 $\left(\mathrm{H}_{4}\right)$ & MK-9 $\left(\mathrm{H}_{4}\right)$ \\
\hline Polar lipid composition* & DPG, PG, PIM, 2PL, GL & DPG, PI, 3PL & DPG, PG, PI, 1PL & DPG, PG, PI, PE, 2PL & Unknown & DPG, PG, PGL \\
\hline Interpeptide bridge & L-Lys $\leftarrow$ L-Glu & L-Lys $\leftarrow$ L-Glu & L-Lys $\leftarrow$ L-Ala $\leftarrow$ L-Ala $\leftarrow$ L-Glu & L-Lys $\leftarrow$ L-Ser $\leftarrow$ D-Asp & L-Lys $\leftarrow$ L-Ser $\leftarrow$ D-Asp & $\begin{array}{c}\text { L-Orn } \leftarrow \text { D-Asp } / \mathrm{L}- \\
\text { Orn } \leftarrow \text { D-Glu }\end{array}$ \\
\hline $\mathrm{G}+\mathrm{C}$ content $(\mathrm{mol} \%)$ & 70 & 71 & 70 & 66 & 74 & $72-76$ \\
\hline
\end{tabular}

* DPG, Diphosphatidylglycerol; PG, phosphatidylglycerol; PI, phosphatidylinositol; PIM, phosphatidylinositol mannoside; PL, unknown phospholipid (number of unknown phospholipids indicated); GL, unknown glycolipid. 
Although isolates $1 \mathrm{~A}-\mathrm{C}^{\mathrm{T}}$ and $3 \mathrm{~A}-1$ could be clearly distinguished from each other by their genomic fingerprints, they shared almost identical protein profiles obtained after separation by SDS-PAGE (results not shown). The degree of DNA relatedness clearly demonstrated that strains $1 \mathrm{~A}-\mathrm{C}^{\mathrm{T}}$ and $3 \mathrm{~A}-1$ are members of a single species. The novel species Georgenia muralis gen. nov., sp. nov. is proposed, with strain $1 \mathrm{~A}-\mathrm{C}^{\mathrm{T}}$ (= DSM $14418^{\mathrm{T}}=\mathrm{CCM} 4963^{\mathrm{T}}$ ) as the type strain. A second strain of the species is strain 3A-1 (= DSM $14419=$ CCM 4964)

\section{Description of Georgenia gen. nov.}

Georgenia (Ge.or.gen'i.a. suff. -ia to denote a locality; N.L. fem. n. Georgenia referring to the village St Georgen in Styria, where strains $1 \mathrm{~A}-\mathrm{C}^{\mathrm{T}}$ and $3 \mathrm{~A}-1$ were isolated).

Cells exhibit a rod-coccus cycle. Rods and cocci occur singly or in small clusters. Cocci are $1 \mu \mathrm{m}$ in diameter, rods are $2 \mu \mathrm{m}$ in length and $1 \mu \mathrm{m}$ in width. Gram-positive, non-sporulating, non-motile. Growth occurs under both aerobic and anaerobic conditions. Oxidase-and catalase-positive. Peptidoglycan type is A $4 \alpha$ with L-Lys $\leftarrow$ L-Glu as the interpeptide bridge (murein type A11.54). Menaquinone type is MK-8 $\left(\mathrm{H}_{4}\right)$. Polar lipids are diphosphatidylglycerol, phosphatidylglycerol, phosphatidylinositol mannoside, two unidentified phospholipids and one unknown glycolipid. The predominant fatty acid is ai-C15:0; significant amounts of ai-C15:1 and i-C14:0 are present. Polyamine content is low. Major polyamines are spermidine and spermine. Phylogenetically, this genus is a member of the suborder Micrococcineae, order Actinomycetales. The type species is Georgenia muralis.

\section{Description of Georgenia muralis sp. nov.}

Georgenia muralis (mu.ra'lis. L. adj. muralis, -le pertaining or belonging to walls).

Morphological, chemotaxonomic and general characteristics are as described for the genus. An unidentified compound is present in the fatty acid profile in significant amounts. Colonies reach a maximum diameter of $2 \mathrm{~mm}$. They are yellow-pigmented, transparent, circular and convex. $N$-Acetyl-D-glucosamine, L-arabinose, $p$-arbutin, D-cellobiose, D-fructose, Dgalactose, gluconate, D-glucose, D-maltose, $\alpha$-D-melibiose, sucrose, salicin, D-trehalose, D-xylose and Dmannitol are assimilated. L-Rhamnose, D-ribose, adonitol, $i$-inositol, maltitol, D-sorbitol, putrescine, acetate, propionate, cis-aconitate, trans-aconitate, adipate, 4-aminobutyrate, azelate, citrate, fumarate, glutarate, DL-3-hydroxybutyrate, itaconate, DLlactate, L-malate, mesaconate, oxoglutarate, pyruvate, suberate, L-alanine, $\beta$-alanine, L-aspartate, L-histidine, L-leucine, L-ornithine, L-phenylalanine, L-proline, L-serine, L-tryptophan, 3-hydroxybenzoate, 4-hydroxybenzoate and phenylacetate are not assimilated. Assimilation of D-mannose is variable. $p$-Nitrophenyl
(pNP) $\beta$-D-galactopyranoside, $\mathrm{pNP} \beta$-D-glucuronide, pNP $\alpha$-D-glucopyranoside, pNP $\beta$-D-glucopyranoside, bis-pNP phosphate, $\mathrm{pNP}$ phenylphosphonate, L-alanine $p$-nitroanilide (pNA) and L-proline pNA are hydrolysed. pNP Phosphorylcholine, 2-deoxythymidine-5'-pNP phosphate and L-glutamate $\gamma$-3-carboxypNA are not hydrolysed. Aesculin, cellulose azur and potato starch are hydrolysed. $\alpha$-Cellulose, casein and Tween 80 are not decomposed. Nitrate is reduced to nitrite. Negative for $\mathrm{H}_{2} \mathrm{~S}$ production, indole production and urease activity. Good growth occurs at 28 and $37^{\circ} \mathrm{C}$, weak growth at $4{ }^{\circ} \mathrm{C}$ and no growth at $44^{\circ} \mathrm{C}$. Good growth occurs at $\mathrm{NaCl}$ concentrations up to $5 \%(\mathrm{w} / \mathrm{v})$, with weak growth at $7 \%(\mathrm{w} / \mathrm{v}) \mathrm{NaCl}$. Growth is observed between $\mathrm{pH} 6$ and 9 . The genomic DNA $\mathrm{G}+\mathrm{C}$ content of strain $1 \mathrm{~A}-\mathrm{C}^{\mathrm{T}}$ is $70 \mathrm{~mol} \%$. Isolated from a medieval wall painting in the church of St Georgen in Styria, Austria.

The type strain is strain $1 \mathrm{~A}-\mathrm{C}^{\mathrm{T}}$ (= DSM $14418^{\mathrm{T}}=$ CCM $4963^{\mathrm{T}}$ ); a second strain of this species is $3 \mathrm{~A}-1$ $(=$ DSM $14419=$ CCM 4964).

\section{ACKNOWLEDGEMENTS}

This work was supported by grants P10730-MOB and P12820-MOB from the Austrian Science Foundation (FWF). We are grateful to Hans Trüper for support in nomenclatural problems.

\section{REFERENCES}

Altenburger, P., Kämpfer, P., Makristathis, A., Lubitz, W. \& Busse, H.-J. (1996). Classification of bacteria isolated from a medieval wall painting. J Biotechnol 47, 39-52.

Altenburger, P., Kämpfer, P., Akimov, V., Lubitz, W. \& Busse, H.-J. (1997). Polyamine distribution in actinomycetes with group B peptidoglycan and species of the genera Brevibacterium, Corynebacterium, and Tsukamurella. Int J Syst Bacteriol 47, 270-277.

Auling, G., Probst, A. \& Kroppenstedt, R. M. (1986). Chemo- and molecular taxonomy of D(-)-tartrate-utilizing pseudomonads. Syst Appl Microbiol 8, 114-120.

Brosius, J., Palmer, M. L., Kennedy, P. J. \& Noller, H. F. (1978). Complete nucleotide sequence of a 16S ribosomal RNA gene from Escherichia coli. Proc Natl Acad Sci U S A 75, 4801-4805.

Busse, H.-J. \& Auling, G. (1988). Polyamine pattern as a chemotaxonomic marker within the Proteobacteria. Syst Appl Microbiol 11, $1-8$.

Busse, H.-J. \& Schumann, P. (1999). Polyamine profiles within genera of the class Actinobacteria with LL-diaminopimelic acid in the peptidoglycan. Int J Syst Bacteriol 49, 179-184.

DSMZ (1998). Catalogue of Strains, 6th edn. Braunschweig: DSMZ.

Felsenstein, J. (1993). PHYLIP (phylogenetic inference package), version 3.5c. Department of Genetics, University of Washington, Seattle, WA, USA.

Funke, G., Ramos, C. P. \& Collins, M. D. (1995). Identification of some clinical strains of CDC coryneform group A-3 and A-4 bacteria as Cellulomonas species and proposal of Cellulomonas hominis sp. nov. for some group A-3 strains. J Clin Microbiol 33, 2091-2097.

GCG (1995). Wisconsin Package Version 8.1 Program Manual. Madison, WI: Genetics Computer Group.

Groth, I., Schumann, P., Rainey, F. A., Martin, K., Schuetze, B. \& Augsten, K. (1997a). Bogoriella caseilytica gen. nov., sp. nov., a new alkaliphilic actinomycete from a soda lake in Africa. Int J Syst Bacteriol 47, 788-794. 
Groth, I., Schumann, P., Rainey, F. A., Martin, K., Schuetze, B. \& Augsten, K. (1997b). Demetria terragena gen. nov., sp. nov., a new genus of actinomycetes isolated from compost soil. Int J Syst Bacteriol 47, 1129-1133.

Groth, I., Schumann, P., Martin, K., Schuetze, B., Augsten, K., Kramer, I. \& Stackebrandt, E. (1999a). Ornithinicoccus hortensis gen. nov., sp. nov., a soil actinomycete which contains L-ornithine. Int $J$ Syst Bacteriol 49, 1717-1724.

Groth, I., Schumann, P., Schuetze, B., Augsten, K., Kramer, I. \& Stackebrandt, E. (1999b). Beutenbergia cavernae gen. nov., sp. nov., an L-lysine-containing actinomycete isolated from a cave. Int $J$ Syst Bacteriol 49, 1733-1740.

Huß, V. A. R., Festl, H. \& Schleifer, K. H. (1983). Studies on the spectrophotometric determination of DNA hybridization from renaturation rates. Syst Appl Microbiol 4, 184-192.

Jahnke, K.-D. (1992). BASIC computer program for evaluation of spectroscopic DNA renaturation data from GILFORD SYSTEM 2600 spectrophotometer on a PC/XT/AT type personal computer. $J$ Microbiol Methods 15, 61-73.

Jukes, T. H. \& Cantor, C. R. (1969). Evolution of protein molecules. In Mammalian Protein Metabolism, vol. 3, pp. 21-132. Edited by H. N. Munro. New York: Academic Press.

Kainz, A., Lubitz, W. \& Busse, H.-J. (2000). Genomic fingerprints, ARDRA profiles and quinone systems for classification of Pasteurella sensu stricto. Syst Appl Microbiol 23, 494-503.

Kämpfer, P., Steiof, M. \& Dott, W. (1991). Microbiological characterization of a fuel oil contaminated site including numerical identification of heterotrophic water and soil bacteria. Microb Ecol 21, 227-251.

Kaneko, T., Katoh, K., Fujimoto, M., Kumagi, M., Tamaoka, J. \& Katayama-Fujimura, Y. (1986). Determination of the nucleotide composition of a deoxyribonucleic acid by high-performance liquid chromatography of its enzymic hydrolysates: a review. $J$ Microbiol Methods 4, 229-240.

Louws, F. J., Fulbright, D. W., Stephens, C. T. \& de Bruijn, F. J. (1994). Specific genomic fingerprints of phytopathogenic Xanthomonas and Pseudomonas pathovars and strains generated with repetitive sequences and PCR. Appl Environ Microbiol 60, 2286-2295.

Martin, K., Schumann, P., Rainey, F. A., Schuetze, B. \& Groth, I. (1997). Janibacter limosus gen. nov., sp. nov., a new actinomycete with meso-diaminopimelic acid in the cell wall. Int $J$ Syst Bacteriol 47, 529-534.

Maszenan, A. M., Seviour, R. J., Patel, B. K. C., Schumann, P., Burghardt, J., Tokiwa, Y. \& Stratton, H. M. (2000). Three isolates of novel polyphosphate-accumulating Gram-positive cocci, obtained from activated sludge, belong to a new genus, Tetrasphaera gen. nov., and description of two new species, Tetrasphaera japonica sp. nov. and Tetrasphaera australiensis sp. nov. Int J Syst Evol Microbiol 50, 593-603.

Moaledj, K. (1986). Comparison of Gram-staining and alternate methods, $\mathrm{KOH}$ test and aminopeptidase activity in aquatic bacteria: their application to numerical taxonomy. J Microbiol Methods 5, 303-310.

Nielsen, P., Fritze, D. \& Priest, F. G. (1995). Phenetic diversity of alkaliphilic Bacillus strains : proposal for nine new species. Microbiology 141, 1745-1761.

Osterhout, G. J., Shull, V. H. \& Dick, J. D. (1991). Identification of clinical isolates of Gram-negative nonfermentative bacteria by an automated cellular fatty acid identification system. J Clin Microbiol 29, $1822-1830$

Pearson, W. R. \& Lipman, D. J. (1988). Improved tools for biological sequence comparison. Proc Natl Acad Sci U S A 85, 2444-2448.

Prauser, H., Schumann, P., Rainey, F. A., Kroppenstedt, R. M. \& Stackebrandt, E. (1997). Terracoccus luteus gen. nov., sp. nov., an LL-diaminopimelic acid-containing coccoid actinomycete from soil. Int J Syst Bacteriol 47, 1218-1224.

Rainey, F. A., Weiss, N. \& Stackebrandt, E. (1995). Phylogenetic analysis of the genera Cellulomonas, Promicromonospora, and Jonesia and proposal to exclude the genus Jonesia from the family Cellulomonadaceae. Int J Syst Bacteriol 45, 649-652.

Saitou, N. \& Nei, M. (1987). The neighbor-joining method: a new method for reconstructing phylogenetic trees. Mol Biol Evol 4, 406-425. Schleifer, K. H. \& Kandler, O. (1972). Peptidoglycan types of bacterial cell walls and their taxonomic implications. Bacteriol Rev 36, 407-477.

Schumann, P., Prauser, H., Rainey, F. A., Stackebrandt, E. \& Hirsch, P. (1997). Friedmanniella antarctica gen. nov., sp. nov., an LLdiaminopimelic acid-containing actinomycete from Antarctic sandstone. Int J Syst Bacteriol 47, 278-283.

Schumann, P., Weiss, N. \& Stackebrandt, E. (2001). Reclassification of Cellulomonas cellulans (Stackebrandt and Keddie 1986) as Cellulosimicrobium cellulans gen. nov., comb. nov. Int J Syst Evol Microbiol 51, 1007-1010.

Smibert, R. M. \& Krieg, N. R. (1994). Phenotypic characterization. In Methods for General and Molecular Bacteriology, pp. 607-654. Edited by P. Gerhardt, R. G. E. Murray, W. A. Wood \& N. R. Krieg. Washington, DC: American Society for Microbiology

Stackebrandt, E. \& Prauser, H. (1992). The family Cellulomonadaceae. In The Prokaryotes - A Handbook on the Biology of Bacteria: Ecophysiology, Isolation, Identification, Application, 2nd edn, pp. 1323-1345. Edited by A. Balows, H.-G. Trüper, M. Dworkin, W. Harder \& K.-H. Schleifer. New York: Springer.

Stackebrandt, E. \& Schumann, P. (2000). Description of Bogoriellaceae fam. nov., Dermacoccaceae fam. nov., Rarobacteraceae fam. nov. and Sanguibacteraceae fam. nov. and emendation of some families of the suborder Micrococcineae. Int J Syst Evol Microbiol 50, 1279-1285.

Stackebrandt, E., Kroppenstedt, R. M. \& Fowler, V. J. (1983a). A phylogenetic analysis of the family Dermatophilaceae. J Gen Microbiol 129, 1831-1838.

Stackebrandt, E., Fowler, V. J., Fiedler, F. \& Seiler, H. (1983b). Taxonomic studies on Arthrobacter nicotianae and related taxa: description of Arthrobacter uratoxydans sp. nov. and Arthrobacter sulfureus sp. nov. and reclassification of Brevibacterium protophormiae as Arthrobacter protophormiae comb. nov. Syst Appl Microbiol 4, 470-486.

Stackebrandt, E., Rainey, F. A. \& Ward-Rainey, N. L. (1997). Proposal for a new hierarchic classification system, Actinobacteria classis nov. Int $J$ Syst Bacteriol 47, 479-491.

Tindall, B. J. (1990). A comparative study of the lipid composition of Halobacterium saccharovorum from various sources. Syst Appl Microbiol 13, 128-130.

Van Belkum, A., Bax, R., Peerbooms, P., Goessens, W. H. F., Van Leeuwen, N. \& Quint, W. G. V. (1992). Comparison of phage typing and DNA fingerprinting by polymerase chain reaction for discrimination of methicillin-resistant Staphylococcus aureus strains. J Clin Microbiol 31, 798-803.

Ventosa, A., Marquez, M. C., Kocur, M. \& Tindall, B. J. (1993). Comparative study of 'Micrococcus sp.' strains CCM 168 and CCM 1405 and members of the genus Salinicoccus. Int J Syst Bacteriol 43, 245-248.

Versalovic, J., Kapur, V., Mason, E. O., Jr, Shah, U., Koeuth, T., Lupski, J. R. \& Musser, J. M. (1993). Penicillin-resistant Streptococcus pneumoniae strains recovered in Houston: identification and molecular characterization of multiple clones. J Infect Dis 167, 850-856.

Wieser, M. \& Busse, H.-J. (2000). Rapid identification of Staphylococcus epidermidis. Int J Syst Evol Microbiol 50, 1087-1093.

Wieser, M., Schumann, P., Martin, K., Altenburger, P., Burghardt, J., Lubitz, W. \& Busse, H.-J. (1999). Agrococcus citreus sp. nov., isolated from a medieval wall painting of the chapel of Castle Herberstein (Austria). Int J Syst Bacteriol 49, 1165-1170.

Woods, C. R., Versalovic, J., Koeuth, T. \& Lupski, J. R. (1992). Analysis of relationships among isolates of Citrobacter diversus by using DNA fingerprints generated by repetitive sequence-based primers in the polymerase chain reaction. J Clin Microbiol 30, 2921-2929. 